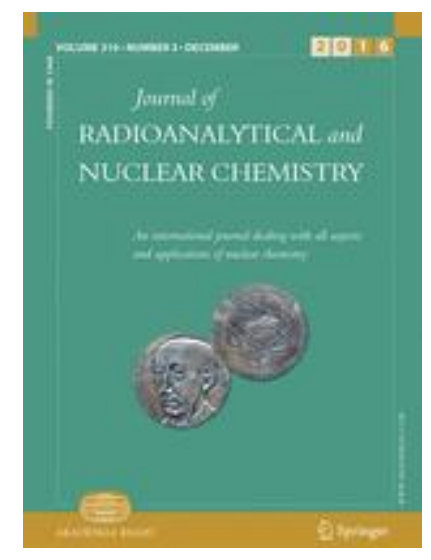

Journal of Radioanalytical and Nuclear Chemistry

pp 1-7

\title{
Radiological and chemical toxicity risks of uranium in groundwater based-drinking at Immigration Headquarters Gosa and Federal Housing Lugbe area of Abuja, North Central Nigeria
}

- Authors

- $\underline{\text { Authors and affiliations }}$

- Omeje MaxwellEmail author

- Husin Wagiran

- Olusegun Adewoyin

- E. S. Joel

- Ngozi Adeleye

- Zaidi Embong

- I. T. Tenebe

- Omeje Maxwell

$$
\begin{array}{ll}
\text { o } & 1 \\
\text { o } & 2
\end{array}
$$

Email author

- Husin Wagiran

$$
\text { o } 2
$$

- Olusegun Adewoyin

$$
\text { o } 1
$$

- E. S. Joel 
- Ngozi Adeleye

$$
\text { o } 3
$$

- Zaidi Embong

o 4

- I. T. Tenebe

o 5

1. 1.Department of Physics, College of Science and TechnologyCovenant UniversityOtaNigeria

2. 2.Department of Physics, Faculty of ScienceUniversiti Teknologi MalaysiaJohorMalaysia

3. 3.Department of Economics and Development Studies, College of Business and Social SciencesCovenant UniversityOtaNigeria

4. 4.Faculty of Science, Technology and Human DevelopmentUniversiti Tun Hussein Onn MalaysiaJohorMalaysia

5. 5.Department of Civil Engineering, College of EngineeringCovenant UniversityOtaNigeria

Article

First Online:

29 August 2016

DOI: $10.1007 / s 10967-016-4997-9$

Cite this article as:

Maxwell, O., Wagiran, H., Adewoyin, O. et al. J Radioanal Nucl Chem (2016). doi:10.1007/s10967-016-4997-9

- 21 Downloads

\section{Abstract}

Inadequate public water supply by the Water Board in Abuja has forced the public to source for groundwater as the only alternative for consumption without consideration for radiological risk. The radiological risk for cancer mortality of uranium in Immigration Headquarters Gosa and Federal-Housing Lugbe groundwater water samples were measured and compared with Water Board and hand-dug well water samples from the same area using inductively coupled plasma mass spectrometry. The highest radiological risks for cancer mortality and morbidity were found to be low, with highest values of $1.24 \times 10^{-7}$ and 1.64 $\times 10^{-7}$ obtained from Federal-Housing Lugbe borehole. The chemical toxicity risk of ${ }^{238} \mathrm{U}$ in drinking water over life time consumption has a mean value of $4.0 \times 10^{-4} \mathrm{\mu g} \mathrm{kg}^{-1}$ day $^{-1}$ with highest value of $6.0 \times 10^{-3} \mathrm{~g} \mathrm{~kg} \mathrm{k}^{-1}$ day $^{-1}$ obtained from Federal-Housing Lugbe.

Significantly, this study inferred that the ${ }^{238} \mathrm{U}$ concentrations reported in groundwater baseddrinking originated from sheared zone of magmatic metamorphosed basaltic dyke intrusion. Due to the low risk values found in the water samples when compared with the International Reference Standard, radiological and chemical toxicity risks values may not pose any health risk to the public that rely on groundwater in the area.

\section{Keywords}


AbujaToxicity riskRadiological riskUranium isotopeDrinking waterGroundwater

\section{References}

1. 1.

Kurttio P, Komulainen H, Leino A, Salonen L, Auvinen A, Saha H (2005) Bone as a possible target of chemical toxicity of natural uranium in drinking water. Environ Health Perspect 113(1):68-72CrossRefGoogle Scholar

2. 2.

Zamora ML, Tracy BL, Zielinski JM, Meyerhof DP, Moss MA (1998) Chronic ingestion of uranium in drinking water a study of kidney bioeffects in humans. Toxicol Sci 43:68-77당sefGoogle Scholar

3. 3.

Frisbie SH, Mitchell EJ, Mastera LJ, Maynard DM, Yusuf AZ, Siddiq MY, Ortega R, Dunn RK, Westerman DS, Bacquart T, Sarkar B (2009) Public health strategies for western Bangladesh that address arsenic, manganese, uranium, and other toxicelements in drinking water. Environ Health Perspect 117(3):410416CrossRefGoogle Scholar

4. 4.

Kumar A, Usha N, Sawant PD, Tripathi RM, Raj SS, Mishra M, Rout S, Supreeta P, Singh J, Kumar S, Kushwaha HS (2011) Risk assessment for natural uranium in subsurface water of Punjab State, India. Hum Ecol Risk Assess 17(2):381393CrossRefGoogle Scholar

5. 5 .

Guo H et al (2016) Contrasting distributions of groundwater arsenic and uranium in the western Hetao basin, Inner Mongolia: implication for origins and fate controls. Sci Total Environ 541:1172-1190CrossRefGoogle Scholar

6. 6 .

Wu Y, Wang YX, Xie XJ (2014) Occurrence, behavior and distribution of high levels of uranium in shallow groundwater at Datong basin, northern China. Sci Total Environ 472:809-817당s:fefGoogle Scholar

7. 7.

Moon SH, Hwang J, Lee JY, Hyun SP, Bae BK, Park Y (2013) Establishing the origin of elevated uranium concentrations in groundwater near the central ogcheon metamorphic belt, Korea. J Environ Qual 42:118-128CrossRefGoogle Scholar

8. 8. 
Stalder E, Blanc A, Haldimann M, Dudler V (2012) Occurrence of uranium in Swiss drinking water. Chemosphere 86(6):672-679CrossRefGoogle Scholar

9. 9.

Selden AI, Lundholm C, Edlund B, Hogdahl C, Ek BM, Bergstrom BE, Ohlson CG (2009) Nephrotoxicity of uranium in drinking water from private drilled wells. Environ Res 109(4):486-494CrossRefGoogle Scholar

10. 10 .

Yang Q, Smitherman P, Hess CT, Culbertson CW, Marvinney RG, Smith AE, Zheng $Y$ (2014) Uraniumand radon in private bedrock well water in Maine: geospatial analysis at two scales. Environ Sci Technol 48:4298-4306CrossRefGoogle Scholar

11. 11.

Buschmann J, Berg M, Stengel C, Winkel L, Sampson ML, Trang PTK, Viet PH (2008) Contamination of drinking water resources in the Mekong delta floodplains: arsenic and other trace metals pose serious health risks to population. Environ Int 34:756-764CrossRefGoogle Scholar

12. 12.

Amakom CM, Jibiri NN (2010) Chemical and radiological risk assessment of uranium in borehole and well waters in the Odeda Area, Ogun State, Nigeria. Int J Phy Sci 5(7):1009-1014Google Scholar

13. 13.

World Health Organization (2011) Guidelines for Drinking-water Quality, 4th edn. WHO, GenevaGoogle Scholar

14. 14.

Kurttio P, Auvinen A, Salonen L, Saha H, Pekkanen J, Mäkeläinen I, Väisänen SB, Penttilä IM, Komulainen H (2002) Renal effects of uranium in drinking water. Enviro Health Perspect 110(4):337-342CrossRefGoogle Scholar

15. 15.

World Health Organization (WHO) (2006) Meeting the MDG drinking water and sanitation target, The urban and rural challenge of the decade. WHO, New York, pp 1-47 Google Scholar

16. 16.

Lucas HF (1985) ${ }^{226} \mathrm{Ra}$ and ${ }^{228} \mathrm{Ra}$ in water supplies. J Am Water Work Assoc 77(9):57-66Google Scholar 
17. 17.

Omeje M, Wagiran H, Ibrahim H, Lee N, Soheil S (2013) Comparison of ${ }^{238} \mathrm{U}$, ${ }^{232} \mathrm{Th}$, and ${ }^{40} \mathrm{~K}$ in different layers of subsurface structures in Dei-Dei and Kubwa, Abuja, Northcentral Nigeria. Radiat Phys Chem 91:70-80CrossRefGoogle Scholar

18. 18.

Pereira-Barbosa JT, Moreira-Santos CM, Bispo LDS, Lyra FH, David JM, AndradeKorn MDG, Moraes-Flores EM (2013) Bromine, chlorine, and iodine determination in soybean and its products by ICP-MS After digestion using microwave- induced combustion. Food Anal Methods 6(4):1065-1070CrossRefGoogle Scholar

19. 19.

Mesko MF, Mello PA, Bizzi CA, Dressler VL, Knapp G, Flores EMM (2010) Iodine determination in food by inductively coupled plasma mass spectrometry after digestion by microwave-induced combustion. Anal Bioanal Chem 398(2):11251131CrossRefGoogle Scholar

20. 20.

Sac MM, Ortabuk F, Kumru MN, Ichedef M (2012) Determination of radioactivity and heavy metals of Bakirc-ay river in Western Turkey. Appl Radiat Isot 70(2012):2494-2499CrossRefGoogle Scholar

21. 21.

Council Directive 98/83/EY/ (1996) The quality of water intended for human consumption. Off J Eur Communites L 330(05/12/1998s):0032-0054Google Scholar

22. 22.

World Health Organization (2003) Guideline for drinking water quality health criteria and other supporting information edition of guidelines on drinking water quality, 2nd edn. WHO, GenevaGoogle Scholar

23. 23.

Kobal I, Vaupotic J, Mitic D, Kristan J, Ancik M, Jerancic S, Skofljanec M (1990) Natural radioactivity of fresh waters in Slovenia, Yugoslavia. Environ Int 16(2):141154CrossRefGoogle Scholar

24. 24.

Koljonen T (1992) The Geochemical Atlas of Finland, Part 2 Till. Espoo. Geolog Surv Finl

25. 25. 
Almeida RMR, Lauria DC, Ferreira AC, Sracek O (2004) Groundwater radon, radium and uranium in Região dos Lagos, Rio de Janeiro State, Brazil. J Enviro. Radio 73(3):323-334CrossRefGoogle Scholar

26. 26.

Omeje M, Husin W (2015) Tectonic and radioactivity impacts of ${ }^{238} \mathrm{U}$ on groundwater based drinking water at Gosa and Lugbe area of Abuja, North Central Nigeria. J Nucl Sci Technol 52(12):1-8Google Scholar

27. 27.

Internal Commission on Radiological Protection (1993) Age-dependent doses to members of the public from intake of radionuclides: Part 2 ingestion dose coefficients, annals on the ICRP, ICRP publication 67. Pergamon Press, OxfordGoogle Scholar

28. 28.

National Research Council (1999) Risk assessment of radon in drinking water. Washinton D.C, National Academy Press $\underline{\text { Google Scholar }}$

29. 29.

World Health Organization (2004) Edition of Guidelines on Drinking Water Quality, 3rd edn. WHO, GenevaGoogle Scholar

30. 30 .

U.S. Environmental Protection Agency (EPA) (1999) Cancer risk coefficients for environmental exposure to radionuclides. United State Environmental Protection Agency. Federal Guidance Report No -13(EPA. 402 R-99-001)

31. 31.

Ye-shin K, Hoa-sung P, Jin-yong K, Sun-ku P, Byong-wook C, Ig-hwan S, Dong Chun S (2004) Health risk assessment for uranium in Korean groundwater. J Environ Radioact 77(1):77-85CrossRefGoogle Scholar

\section{About this article}

CrossMark

Print ISSN

0236-5731

Online ISSN

$1588-2780$

Publisher Name

Springer Netherlands 